\title{
Perceptions of employers and unemployed youth on the proposed youth employment wage subsidy incentive in South Africa: A KwaZulu-Natal study
}

\begin{abstract}
Authors:
Vuyokazi N. Mtembu ${ }^{1}$

Loganathan N. Govender ${ }^{2}$

Affiliations:

${ }^{1}$ Graduate School of Business and Leadership, University of KwaZulu-Natal, South Africa

${ }^{2}$ School of Management, Information Technology and Governance, University of KwaZulu-Natal, South Africa

Correspondence to:

Vuyokazi Mtembu

Email:

vmtembu@mighty.co.za

Postal address:

72 JB Marks Road, Unit 5 Algwen, Glenwood, Durban 4000, South Africa

\section{Dates:}

Received: 26 June 2014

Accepted: 27 Feb. 2015

Published: 02 June 2015

How to cite this article: Mtembu, V.N., \& Govender, L.N. (2015). Perceptions of employers and unemployed youth on the proposed youth employment wage subsidy incentive in South Africa: A KwaZulu-Natal study. SA Journal of Human Resource Management/SA Tydskrif vir Menslikehulpbronbestuur 13(1), Art. \#653, 9 pages. http://dx.doi.org/10.4102/ sajhrm.v13i1.653

\section{Copyright:}

C 2015. The Authors.

Licensee: AOSIS

OpenJournals. This work is licensed under the Creative Commons Attribution License.
\end{abstract}

\section{Read online:}

Orientation: South Africa has high levels of unemployment and severe problem of youth unemployment. This implies that the country requires a comprehensive strategy to create more jobs for the youth. Policymaking is one of the strategies that have been introduced to encourage job creation for the youth. The youth wage subsidy is just one of the strategies proposed and this article unpacks what employers and unemployed youth say and think about this policy directive.

Research purpose: The main aim of the study was to determine the perceptions of unemployed South African youth and employers on the proposed youth wage subsidy incentive scheme.

Motivation for the study: Youth unemployment is a very important issue and the reality is that it is a concern of every government globally. South Africa is therefore not an exception as it is a country that has been experiencing high levels of youth unemployment for the last few decades. In an attempt to curb this pressing challenge of youth unemployment, a proposal to introduce a youth wage subsidy policy was made by government; (since its mention), this idea has been met with a lot of opposing opinions from those against it and applause from those who support it. This has motivated this study to probe the perceptions of the subsidy by those who will be affected by its provisions.

Method: A triangulated research approach was adopted through the administration of survey questionnaires amongst the unemployed youth and semi-structured interviews with human resource managers and specialists. A sample of unemployed youth was drawn from selected communities within KwaZulu-Natal. In addition, semi-structured interviews were conducted with human resource managers and specialists at selected organisations to determine their perceptions of the proposed scheme and any benefits or limitations they believe it might have. Non-probability sampling was used to sample 100 respondents $(N=100), 90 \%$ of whom were unemployed youths and $10 \%$ of whom were employers.

Main findings: The overall results indicate that more that $93 \%$ of the youth surveyed and more than $90 \%$ of employers are in support of the youth wage subsidy. In terms of how it should be structured and implemented, about $80 \%$ of respondents in the employer survey preferred the tax rebate and incentive option as most of them stated that it will be an easier process to manage and monitor. More than $50 \%$ of employers believed that it will ease the wage burden and ensure business sustainability. On the other hand, $88 \%$ of the youth surveyed believed it will increase employment for the youth. Findings furthermore reveal that $10 \%$ of employers and $28 \%$ of the youth were concerned that the subsidy has the potential to exploit older workers (i.e. those who are already in employment) and feared corruption from some employers; otherwise they are in support of its implementation.

Contribution: This is one of the areas that have not been sufficiently explored; as a result, there is not much information about it in the current body of knowledge. This study will contribute to current knowledge about a current policy initiative critical to the development of the country. This research also culminates in important recommendations and draws conclusions that could contribute to the formulation of guidelines on how the government could embrace the youth wage subsidy incentive scheme as a strategic intervention that could benefit the employers and the youth and at the same time aid in finding a solution to South Africa's youth unemployment crisis.

\section{Introduction}

South Africa has a severe problem of youth unemployment, which requires a multi-pronged strategy to raise employment and support inclusion and social cohesion (National Treasury, 2011, p. 5). High youth unemployment means that young people are not receiving the skills and 
experience that are required to drive the economy forward. The high youth unemployment rate inhibits the country's economic development and poses a huge burden on the state to provide social assistance (National Treasury, 2011, p. 5).

Statistics South Africa's (2013) quarterly labour force survey reports that in the first quarter of 2013 the number of unemployed reached 4.6 million; $65.3 \%$ had been looking for work for a period of one year or longer and $59.4 \%$ of the job seekers did not have matric. The unemployment rate amongst the 15-24 year olds (52.9\%) remains the highest amongst all age groups and has been on the increase. The 15-34 year olds accounted for $70.7 \%$ of the unemployed persons in the country.

The alarming statistics on high youth unemployment ignited an interest to probe and conduct a study on this issue. Hence, the main aim of this study is to determine the perceptions of employers and unemployed youth on the proposed youth employment incentive scheme aimed to address this challenge and the epidemic of high youth unemployment in South Africa. In light of the findings, the study will recommend and suggest solutions for this national problem.

In his inaugural State of the Nation Address, President Jacob Zuma stated:

The creation of decent work will be at the centre of our economic policies and will influence our investment attraction and job creation initiatives. In line with our undertakings, we have to forge ahead to promote a more inclusive economy. There is growing consensus that creating decent work, reducing inequality and defeating poverty can only happen through a new growth path founded on restructuring the South African economy to improve its performance in terms of labour absorption and rate of growth. (South African Government, 2010, n.p.)

In putting the president's words into action, to establish a new growth path that will create an environment for economic growth and decent work creation, government, under the leadership of Minister Ebrahim Patel, on 23 November 2010 released the Framework of the New Economic Growth Path, aimed at enhancing growth, employment creation and equity. The policy's principal target is to create five million jobs over the next 10 years (South African Government, 2010).

The new growth path framework document states that:

to achieve the step of creating decent work, reducing inequality and defeating poverty, change in growth and transformation of economic conditions requires hard choices and a shared determination as South Africans to see it through. The Government is committed to forging such a consensus and leading the way by Identifying areas where employment creation is possible on a large scale and developing a policy package to facilitate employment creation. (South African Government, 2010, n.p.)

One of the elements of the policy package referred to is the proposed youth wage subsidy policy, which was highlighted in the medium term budget policy statement in 2009 and formally announced by President Zuma in the State of the Nation Address in February 2010 and whose paper for public comment was released by the National Treasury in February 2011. The youth wage subsidy was envisaged to be implemented from 01 April 2012, but due to differences in views from various stakeholders including political parties, business and labour the implementation process has been delayed to date (2013).

\section{Literature review Unemployment in South Africa}

The definition of unemployment according to Statistics South Africa is:

when someone aged between 15 and 64 is without work in the week preceding the interview, but who looks for work and is available to take up employment or open a business. (Statistics South Africa, 2013, n.p.)

Statistics South Africa's (2013) expanded definition of unemployment on the other hand includes people who have stopped looking for work, who can be referred to as discouraged work seekers. According to the narrow definition of unemployment, in the first quarter of 2013, South Africa's official unemployment was 25.2\% from $24.9 \%$ in the fourth quarter of 2012; however, in the expanded definition statistics, which include people who have stopped looking for work, the unemployment rate was $36.7 \%$ in the first quarter of 2013, the highest since 2008.

In principle, unemployment is easy to define. Persons are unemployed if they desire employment but cannot find jobs. The unemployment rate is then obtained by expressing the number of unemployed persons as a percentage of the total number of people willing and able to work, the so-called labour force (South African Reserve Bank, 2013).

Globally, a country's unemployment is defined as a number of jobless people as a percentage of the total labour force (economically active people). Persons are unemployed if they are in an economically active group, would like to be working but are unable to find work. One of the general definitions used in most academic books is the one given by Roux (2008), who defines unemployment or the unemployed as:

those people who are 15 and older (normally below 65), are currently unemployed, but are available for employment within the next 2 weeks and have taken specific steps during the last 4 weeks to find employment. (p. 56)

Roux (2008, p. 51) on the challenge of unemployment describes it as 'one of the major socio-economic problems in South Africa, unemployment implies hunger, misery and loss of self-esteem for those who are jobless'. Roux continues to describe unemployment as leading to anger and resentment towards a system that has led to people's inability to find a meaningfuljob. In South Africa, unemployment is particularly high. As a result, the potential for socio-economic instability is not only great, but also extremely worrying (Roux, 2008, 
p. 51). The prevalence of service delivery strikes, community unrest and public violence are clear manifestations of the frustration of a jobless South African society living in poverty with no sense of hope. This then gives a strong message to government and other social and economic partners to give this issue priority attention.

Barker (2007, pp. 172-173) describes unemployment as 'probably the most severe problem in South Africa and is conceivably the root cause of many other problems such as crime and violence'. Barker continues to explain why unemployment should be addressed by stating that:

the reason why job creation should be the highest policy priority is because unemployment has grave consequences for any country, it not only affects an individual's dignity and self-respect and erodes his or her standard of living, but also affects society as a whole because of high crime rates and frustration leading to unrest and lawlessness. (Barker, 2007, pp. 172-173)

\section{Causes of unemployment or types of unemployment}

In academic literature, causes of unemployment are usually categorised into the following:

- Structural - overall inability of the economy to provide jobs, owing to structural imbalances sometimes even during periods of economic growth, for example as a result of skills mismatch, rapid growth of labour force and so on.

- Seasonal - due to normal and expected changes in economic activity, for example agriculture and the retail trade.

- Cyclical - demand deficient unemployment, for example during times of recession, demand for labour is low.

- Frictional - arises as result of normal labour turnover in a dynamic economy, time lags involved between re-employment of labour (Natrass, Wakeford \& Muradzikwa, 2002, pp. 176-177).

Parsons (2009) states that:

one other reason why the unemployment rate has stayed high in South Africa is the structural impediments, as the large part of the population has been immobilised and incapacitated, a number of structural rigidities prevent them from being employed or participating in any form of income generating economic activity. (p. 18)

Parsons furthermore explains that causes of structural unemployment include:

mismatches between skills supplied and demanded, insufficient access to effective education and skills development opportunities, deterioration of skills and motivation of individual jobseekers caused by prolonged period of unemployment, insufficient opportunities for on the job training and lack of mobility as a results of exacerbated transport costs. (Parsons, 2009, p. 18)

The high rate of youth unemployment is a major problem in the country. According to the National Treasury (2011, p. 5) discussion paper, the following are some of the reasons why youth unemployment is still a severe problem in South Africa:

- Employers look for skills and experience; they regard unskilled, inexperienced jobseekers as a risky investment.

- Education is not a substitute for skills. Schooling is not a reliable signal of capabilities and low school quality feeds into poor workplace learning capacity.

- Given the uncertainty about the potential of school leavers, employers consider entry-level wages to be too high relative to the risk of hiring inexperienced workers.

\section{The identified need for a youth wage subsidy in South Africa}

In an desperate attempt to minimise unemployment and its negative consequences many countries in the world have opted for the strategy of wage subsidies, by either subsidising the payrolls of employers who employ groups of people targeted by the subsidy or by giving tax rebates to such employers as a way of encouraging them to employ more people. In order to consider youth wage subsidies as a means to resolving the current challenge, it is important to determine what wage subsidies entail.

Wage subsidies are usually custom designed to address unemployment challenges facing a certain group of the population, which usually leads to the whole nation being affected by that challenge. This extract from the World Bank policy primer publication gives a clear summary of how wage subsidies are structured:

Wage subsidies come in different forms, pursuing different but related objectives. Subsidies can be given to employers to stimulate demand or to employees to provide incentives for re-employment. They can take the form of direct transfers, reductions in social security contributions, or income tax credits. They can be targeted to vulnerable workers or be provided across the board. They can focus on those already employed or only on new hires. Choices at all these levels determine their impact on employment and their costs. In the context of the crisis of unemployment, wage subsidies have two main functions: dampening the pace of job destruction in the formal sector, avoiding the depreciation of skills and stimulating hiring and facilitating re-employment. In the first case, the subsidies allow employers to keep workers who would otherwise fill the ranks of the unemployed or move to lower productivity jobs in the informal sector-in both cases risking losing their skills. In the second case, the focus is to increase exit rates from unemployment particularly among unemployed poor and vulnerable workers, thus reducing the destructive persistence of long term unemployment. (World Bank, 2009, p. 2)

\section{According to Baskin (1996):}

there are many different ways to design a wage subsidy policy, these include wage subsidies that are either targeted or general, targeted wage subsidies are aimed specifically at a particular region or demographic group, when targeted at a disadvantaged subset of the entire potential labour force, they are known as categorical wage subsidies, these might be designed specifically to help unskilled workers, poor families or the youth. (p. 191) 
Wage subsidies often take the form of a tax credit whose downside is the decrease in financial resources, in some cases, the increased levels of employment will produce savings in social insurance programmes, such as unemployment insurance, social grants and other transfer payments which will replenish a portion of the programme's cost. (Baskin, 1996, p. 194)

The design of a wage subsidy and which group it targets is very important as it can have implications on the cost of the subsidy and its impact in minimising the challenge of unemployment and poverty. According to the World Bank (2009):

employer-based subsidies can cost less and have a larger social impact if targeted to individuals with lower pay. Their main role is to smooth the impact of a temporary downturn. While on the other hand targeted employee-based subsidies linked to other active labor market programs such as training and job counseling can be considered to improve the employability of low-income unskilled workers over the medium-term. (p. 2)

One of the first and most comprehensive studies done in South Africa on the effect of youth wage subsidies in employment was first conducted in 2011 (SBP, 2013). The study surveyed about 500 small and medium enterprises on their views on the youth wage subsidy. Findings of the study indicated that $55 \%$ of firms surveyed were in favour of the youth wage subsidy. A majority of firms employing between 10 and 40 people supported the subsidy; this was especially pronounced amongst those employing between 31 and 40 people, a group within which a great deal of business expansion appears to be taking place. Around $75 \%$ of firms employing between 31 and 40 people supported the subsidy. Support for the subsidy was highest in the manufacturing sector (SBP, 2013, p. 31).

Another study conducted in South Africa was a study undertaken by the African Micro-economic Research Unit (AMERU) at the University of Witwatersrand (Rankin \& Schöer, 2011). The study tracked 4000 unemployed young people aged between 20 and 24 years and more than 600 firms, over a period of 3 years. Part of this research included testing the impact of a R5000 hiring voucher allocated to 4000 youth, which was to expire in 6 months. The youth was tasked to find work. If they found work their employers were allowed to claim R5000 from Wits University. Preliminary results showed that half the sample who received hiring vouchers was likely to find employment as compared to those who had no vouchers (Rankin \& Schöer, 2011).

\section{The main findings of the research included the following:}

young people who were allocated a hiring voucher were up to 25 per cent more likely to be employed than those who were not. This effect persisted 2 years after the hiring voucher was allocated. Another finding of this study was that the majority of firms stated they would not substitute older workers for younger ones if there was a youth employment incentive, in part because older workers are more reliable and experienced. (Rankin \& Schöer, 2011)

\section{Research design}

In this study, objectives and specific questions were formulated, a systematic system of finding answers was followed with the use of questionnaires distributed to unemployed youth in KwaZulu-Natal and interviews conducted with human resource managers and specialists in various companies within KwaZulu-Natal.

\section{Research questions were the following}

- What are the perceptions of employers and unemployed youth on the youth wage subsidy policy?

- Will the youth wage subsidy be supported or rejected by those affected by its provisions?

- Will the youth wage subsidy increase the chances for the youth to get long-term employment?

\section{Research hypotheses}

The research study investigated the following hypotheses:

- Hypothesis 1:

- Ho: Employers and the unemployed youth will not support the youth wage subsidy scheme.

- Ha: Employers and the unemployed youth will support the youth wage subsidy scheme.

\section{- Hypothesis 2:}

- Ho: Youth wage subsidy will result in no increase in jobs for the youth.

- Ha: Youth wage subsidy will result in increase in jobs for the youth.

\section{Exploratory and descriptive research}

A combination of exploratory and descriptive research was used. In this study perceptions and attitudes of South Africa's youth and employers towards youth wage subsidies were solicited, as a way to predetermine chances of success or failure if the proposed youth wage subsidy is implemented. Literature review confirmed that this area of study has never been comprehensively researched before. The exploratory research was conducted to deeply investigate the problem of youth unemployment and to look at possible options and alternatives that can be considered to deal with the challenge of unemployment.

\section{Sampling}

Non-probability sampling was used to sample 100 respondents, $90 \%$ of whom were unemployed youths and $10 \%$ of whom were employers. A combination of convenience, quota and snowball sampling methods was a guiding compass in the selection of relevant respondents. Convenience sampling was used as the researcher sampled only the youth who reside in the province of Kwa-Zulu Natal, which is close to the researcher. Quota sampling was applied in the sense that only a certain category of the youth was sampled: youth between the ages of 18-29 who are not employed and not studying. Snowball sampling came into play as youth members researched were allowed to give references to some of their peers who are in the same situation, who were then also included in the sample. 
TABLE 1: Descriptive statistics perceptions: Youth survey.

\begin{tabular}{|c|c|c|c|c|}
\hline Summary statistics & $\begin{array}{l}\text { Support of youth } \\
\text { wage subsidy }\end{array}$ & $\begin{array}{l}\text { Good idea for youth } \\
\text { employment }\end{array}$ & $\begin{array}{l}\text { Against implementation } \\
\text { of youth wage subsidy }\end{array}$ & $\begin{array}{l}\text { Neither for nor against } \\
\text { subsidy }\end{array}$ \\
\hline Valid $(N)$ & 90 & 90 & 90 & 90 \\
\hline Missing $(N)$ & 0 & 0 & 0 & 0 \\
\hline Mean & 4.38 & 4.41 & 2.33 & 2.78 \\
\hline Standard error & 0.090 & 0.079 & 0.137 & 0.126 \\
\hline Median & 5.00 & 5.00 & 2.00 & 3.00 \\
\hline Mode & 5 & 5 & 1 & 3 \\
\hline Standard deviation & 0.856 & 0.748 & 1.298 & 1.197 \\
\hline
\end{tabular}

\section{Data collection methods}

\section{Questionnaires}

Questionnaires were distributed to respondents who in this case were the unemployed youth $(n=90)$ between the ages of 18 and 29 in KwaZulu-Natal. A questionnaire with 15 questions, which were a combination of structured, semistructured and unstructured questions, was administered to the 90 participating youths. The type of questions was a mix of open and closed ended questions. The closed questions were in the form of a five-point Likert scale.

\section{Semi-structured In depth interviews}

Semi-structured interviews were conducted with employers $(n=10)$ from small, medium and large companies in KwaZuluNatal. The questionnaire comprised seven questions: five open-ended questions and two closed ended.

\section{Ethical considerations}

Anonymity of responses was ensured as respondents were advised not to disclose their names, and were assured that the information will be used for academic research purposes; in that effect anonymity was therefore guaranteed. Participation was voluntary and participants were informed that they can withdraw from the study at any point if they wish to do so.

\section{Data analysis techniques}

Descriptive and inferential statistics were used to analyse the results from the quantitative data collected from the youth questionnaires. SPSS version 21 was used to statistically analyse the data collected. Thematic analysis was used to analyse the qualitative data collected from employer interviews.

\section{Validity and reliability of results}

Cronbach's alpha was used to ensure reliability and quality of results. There are a number of different reliability coefficients. Commonly used is the Cronbach's alpha. The Cronbach's alpha can range from 0 to 1 . Cronbach's alpha was also calculated as part of the reliability test to assess how consistent the results were; all variables were above 0.7 in this study.

\section{Results}

The overall results indicate that $93 \%$ of the youth surveyed and more than $90 \%$ of employers are in support of the youth wage subsidy. In terms of how it should be structured on implementation, about $80 \%$ of respondents in the employer survey preferred the tax rebate incentive option as most of them stated that it will be an easier process to manage and monitor. More than $50 \%$ of employers believed that it will ease the wage burden and ensure business sustainability. Ten percent of respondents indicated that their concern is the subsidy's potential to exploit older workers and corruption from some employers; otherwise they are in support of its implementation.

\section{Results from youth questionnaires: Quantitative assessment}

\section{Descriptive statistics}

Descriptive statistics describe a body of data. Here we discuss how to determine three things we might want to know about a dataset: points of central tendency, amount of variability, and the extent to which different variables are associated with one another. (Leedy \& Ormrod, 2010, p. 265)

In this study, a five-point Likert scale was used to scale responses in the youth questionnaires.

In terms of youth perceptions, Table 1 reflects that the mean for support of wage subsidy was 4.38, which indicates that most respondents fully agreed that they are in support of the youth wage subsidy. For the question on whether it was a good idea for youth employment, the mean was 4.41 , which also shows that most respondents fully agreed that it was a good idea for youth employment. On the third question, which asked whether they were against implementation, the mean was very low at 2.33, which indicates that most respondents disagreed with the statement, meaning that they agreed that it should be implemented. The mode under the variable perceptions is 5 , which indicates that strongly agree was the dominant response in the four questions that were posed under the perceptions variable.

\section{Inferential assessment}

Correlation analysis was carried out to determine the relationship between different variables of the perceptions of youth and employers on the proposed youth wage subsidy. The results are shown in Table 2 .

This correlation relates to hypothesis 1 and hypothesis 2 as these hypotheses look at the support of the youth wage subsidy by employers and youth and the job creation 
TABLE 2: Correlations: hypothesis 1 and hypothesis 2 (Perceptions).

\begin{tabular}{llll}
\hline Hypothesis & Correlation & $\begin{array}{l}\text { Support of youth } \\
\text { wage subsidy }\end{array}$ & $\begin{array}{l}\text { Good idea for } \\
\text { youth employment }\end{array}$ \\
\hline $\begin{array}{l}\text { Support of youth } \\
\text { wage subsidy }\end{array}$ & $\begin{array}{l}\text { Pearson correlation } \\
\text { Significance }\end{array}$ & 1 & $0.668^{* *}$ \\
& (two-tailed) & - & 0.000 \\
& $N$ & 90 & 90 \\
$\begin{array}{l}\text { Good idea for } \\
\text { youth employment }\end{array}$ & Pearson correlation & $0.668^{* *}$ & 1 \\
& $\begin{array}{l}\text { Significance } \\
\text { (two-tailed) }\end{array}$ & 0.000 & - \\
& $N$ & 90 & 90 \\
\hline
\end{tabular}

**, Correlation is significant at the 0.01 level (two-tailed).

TABLE 3: Chi-squared test.

\begin{tabular}{lll}
\hline Statistical test & $\begin{array}{l}\text { Support of youth wage } \\
\text { subsidy }\end{array}$ & $\begin{array}{l}\text { Good idea for youth } \\
\text { employment }\end{array}$ \\
\hline Chi-squared & 109.556 & 112.556 \\
Asymptotic significance & 0.000 & 0.000 \\
\hline
\end{tabular}

potential of the youth wage subsidy. The correlation coefficient is 0.668 , which indicates that there is a moderately positive relationship that exists between these two variables. This relationship indicates that those who are in support of the youth wage subsidy also to some extent believe that this will be an engine for job creation for the youth since a positive relationship means that a change in one variable influences a change in another in the same direction.

The two-tailed significance $(p)$ value is 0.000 , which is less than 0.05 ; because of this, we can conclude that there is a statistically significant correlation between the support of youth wage subsidy by employers and youth and the job creation potential of the youth wage subsidy.

\section{Chi-square test-perceptions}

Chi-square tests are used when a set of observed frequencies is compared with a set of theoretical (expected) frequencies (Tustin et al., 2005, p. 609).

Chi-square tests were used in this study to compare frequencies in observed (empirical) data and theoretical (expected) data on a number of variables that relate to the perceptions of employers and the unemployed youth on the proposed youth wage subsidy scheme.

As reflected in Table 3, our alpha value is 0.05. If the twosided asymptotic significance for the Pearson chi-square statistic is less than 0.05 , there is a relationship between the variables based on the $95 \%$ level of confidence. As seen in Table 3, the chi-square significance value is 0.000 , which is less than our cut-off value of 0.05 , which shows that there is a relationship between the support of youth wage subsidy by employers and youth with the idea that it is a good strategy for creating youth employment.

At $5 \%(\mathrm{a}=0.05)$, Ho will be rejected if the $\mathrm{p}$-value (asymptotic significance) is less than 0.05 . Thus, Ho is rejected in both of the variables in Table 3 and Ha is accepted. It is concluded that employers and the unemployed youth support the youth wage subsidy scheme and believe that the youth wage subsidy will result in jobs increase for the youth.
TABLE 4: Reliability test.

\begin{tabular}{llll}
\hline Variable & Cronbach's alpha & $\begin{array}{l}\text { Cronbach's alpha based on } \\
\text { standardised items }\end{array}$ & $N$ \\
\hline Perceptions & 0.796 & 0.801 & 2 \\
$\begin{array}{l}\text { Benefits and } \\
\text { limitations }\end{array}$ & 0.768 & 0.769 & 2 \\
Implementation & 0.706 & 0.712 & 2 \\
\hline
\end{tabular}

Cronbach's alpha was calculated as part of the reliability test to assess how consistent the results were (see Table 4). A value of 0.7 or higher is a very good value, which means that if the survey was carried out with a larger sample of respondents, the same results would have been arrived at; 0.7 is the reliability, which is acceptable according to Cronbach's requirements (Coakes \& Steed, 2007, p. 140). In this study alpha values for all variables were above 0.7 .

\section{Results from employer questionnaire: Qualitative results}

Themes that came up in the qualitative analysis were:

- Support of youth wage subsidy.

- Subsidy's potential to create jobs.

- Implementation strategy of the subsidy.

\section{Support of wage subsidy}

In the question on whether they supported or were against the youth wage subsidy, 9 out of 10 participants indicated that they were in support of the wage subsidy. Amongst the reasons given by the $90 \%$ who were in support of the subsidy were that they believed it will develop skills for youth, provide work experience, increase youth employment, reduce socio-economic problems especially crime, relieve the wage burden, develop the economy, sustain businesses and avoid retrenchments.

One of the participants in emphasising her support even went on to say:

'I believe this will be a much needed relief to South Africa's chronic challenge of high youth unemployment. Policies have come and gone, Presidents have come and gone many strategies have been devised and tried to deal with this challenge of unemployment most if not all have failed so far, why not give this one a chance as well and see.' (Human resources specialist, employer, female, 25-30 years old)

The one participant who was against the introduction of the subsidy stated that it will be poorly implemented and will eventually be a failure; in her own words as she was adamantly against it:

'Umsobomvu now NYDA [National Youth Development Agency] is one of the agencies which is mandated to address the challenge of youth unemployment in this country, we have seen these institutions fail, what will make this new initiative to succeed.' (Human resources specialist, employer, female, 30-40 years old)

The above statement is very important and it calls for government to be really strategic this time around if they decide to implement the wage subsidy incentive scheme. 
This they can do by ensuring that perfect planning is in place, expert resources are deployed strategically and accountability is carefully and strictly adhered to. This to ensure that this will not follow in the footsteps of all other previous policies and institutions that have failed to deal with this challenge of youth unemployment in South Africa.

\section{Subsidy's potential to create jobs}

When asked the question of what they think will be the effect will be of this youth wage incentive for both the unemployed youth and employers and in job creation in the country, the responses were as follows: $50 \%$ of the participants mentioned that it will open opportunities for training and skills development for the youth as well as create muchneeded employment opportunities for the young. One of the respondents put it this way:

'Companies will be encouraged to employ the youth, by doing so skills will be developed, experience gained, breadwinners will increase and poverty will decrease.' (Labour relations manager, employer, male, $30-40$ years old)

Forty percent of respondents emphasised that this will be beneficial in providing work experience for our youth; one respondent articulated it in this way:

\begin{abstract}
'As recruiters, in the majority of the job adverts that we publicise one of the main requirements we always want from applicants is work experience, doesn't matter how long it is, it can be 1, 2 or 10 years work experience but it is guaranteed that work experience is always the main requirement when recruiting in this country. The youth wage incentive I believe will help our youth to gain that work experience.' (Human resources manager, employer, male, $30-40$ years old)
\end{abstract}

One respondent also mentioned that they believed it will minimise retrenchments as employers will now have a helping hand from government in terms of wage costs. The one respondent who is against this incentive mentioned that she foresees its failure; she thinks it will benefit only a few urban youth.

In answering the specific question on what effects the wage subsidy will have specifically have on employers, $50 \%$ of participants mentioned that it will be highly beneficial to employers as it will reduce the wage burden. One respondent put it this way:

'Payroll is the biggest cost and largest expenditure item in any company's budget; if this incentive scheme can be truly realised, it will bring some relief to the wage burden that most South African companies are faced with, especially in this era of radical unionism placing high wage demands on employers.' (Human resources manager, employer, male, 30-40 years old)

\section{Discussion of results}

\section{Support of youth wage subsidy and its potential as a job creation strategy}

In the youth questionnaire, youth perceptions revealed that the majority were strongly in support of a wage subsidy, $51 \%$ strongly agreed that it will be a good idea for job creation and $42 \%$ agreed; $7 \%$ were not in support of the subsidy. In terms of benefits and limitations, $88 \%$ agreed that the youth wage subsidy will bring benefits in terms of increasing jobs for the youth, $13 \%$ agreed that there is the possibility of waste of money and a disturbing $28 \%$ agreed that though the subsidy could be a good idea for job creation for the youth, the possibility of corruption must not be ignored. In terms of implementation method, a total of $74 \%$ (strongly agree and agree) preferred that the subsidy be provided to employers in the form of grants whilst $40 \%$ preferred tax rebates (this includes respondents who liked both options).

In the employer survey, $90 \%$ indicated support of the wage subsidy in this study; this corresponds with Rankin and Schöer's (2011) findings in which most small business employers were in full support of the subsidy, as well as the findings from the SME Growth Index research, which also in its findings mentioned that 'around $75 \%$ of firms employing between 31 and 40 people supported the subsidy, support for the subsidy was highest in the manufacturing sector' (SBP, 2013). The high support of the subsidy by employers is indicative of what was reiterated many times in this study that the high cost of wages in South Africa stifles economic growth and increase in employment; hence, they see the youth wage subsidy as a much-needed relief in this area.

\section{Implementation of youth wage subsidy}

In the youth assessment, $62 \%$ were in full support of the subsidy's implementation with $17 \%$ against subsidy implementation, $15 \%$ undecided and $6 \%$ were strongly against implementation of the youth wage incentive. In the employer's interviews, $90 \%$ of respondents from the interviews agreed with the implementation of the subsidy and $10 \%$ were against its implementation.

\section{Practical implications and recommendations}

Various policies and strategies can be considered in an attempt to address the problem of youth unemployment. According to the National Treasury (2011, pp. 18-26), the following are some of the options that government can consider:

- Economic growth: South Africa needs growth policies that are conducive to economic growth and labour demand.

- Education: work integrated learning should be emphasised in our curriculum at all levels of our education system. This will ensure that by the time our youth graduate from tertiary level, they will be fully equipped with practical work exposure.

- Labour market policy: South Africa has one of the most progressive active labour market policies on paper; they now need to be put in action effectively.

- Training programmes: job preparation strategies such as training programmes play a vital role in economic growth of the country.

- Direct public sector employment: South Africa's took one of the right steps in the adoption of Expanded Public 
Works Programmes (EPWP) to deal with the challenge of unemployment.

\section{National Youth Development Agency programmes}

The Graduate Development Programme (GDP) and Job Preparation Programme (JPP) aim to enhance the employability of jobless graduates and matriculants.

The National Youth Service assists unemployed youth to acquire skills whilst providing community services.

The following strategies need to be considered in the creation of more jobs for the youth (as adapted from National Treasury, 2011, pp. 18-26):

- Employment incentives and subsidies: wage or employment subsidies are incentives that aim to accelerate job creation and raise employment.

- Entrepreneurial schemes: entrepreneurship schemes promote skills in young people with the objective of creating and managing sustainable and efficient businesses capable of providing permanent jobs and employment growth.

- Comprehensive approach: finally, there are many examples of countries adopting comprehensive active labour market programmes that implement two or more of the active labour market policies outlined above.

The following are some of the other methods and strategies that South Africa needs to emphasise and intensify in the fight against youth unemployment: learner-ships, internships, apprenticeships, artisans programmes, mentorship programmes, skills training and development and expanded public works programmes.

\section{Institutions that are mandated to fight and curb youth unemployment in South Africa}

Institutions such as the National Youth Development Agency, the Small Enterprise Development Agency, Youth Council, Youth Employment Index, Youth Chamber of Commerce and Industry, skills education training authorities (SETAs) and municipalities, if they work collaboratively to come up with common and progressive strategies, can play a major role in decreasing and further curbing the high youth unemployment rate in the country.

A number of government departments such as Labour, Agriculture, Minerals and Energy, Trade and Industry and Economic Development also need to focus on this issue.

\section{Legislative framework or prescripts and policies}

South Africa has one of the best legislative frameworks that talks to the issues of youth employment and development of the country in general. The mandates from the following laws and prescripts need to be strongly put into action, enforced and monitored strictly:

- National Youth Commission Act (No. 19 of 1996)

- Skills Development Act (No. 97 of 1998)
- Skills Development Levies Act (No. 97 of 1998)

- Human Resource Development Strategy for South Africa (2010-2030)

- National Skills Development Strategy 3 (NSDS III)

- The 12 outcomes of government National Skills Accord National Small Business Amendment Act (No. 29 of 2004)

- National Development Plan

- New Growth Path (2011).

This should be done to ensure that not only does South Africa have attractive laws and prescripts on paper, but also that such prescripts are implemented for the benefit and progress of the nation at large.

Labour laws need to be relaxed as well to allow employers to comfortably do business in this country and to create much-needed employment without being threatened by rigid labour laws that are mainly skewed in favour of labour. The issue of high wage demands from labour, which makes doing business in this country unsustainable for small to medium struggling enterprises, also needs to be dealt with accordingly.

\section{Limitations}

In this area of research at present, locating and sourcing of literature posed serious challenges. Further limitations were the lack of comparative studies as South Africa is a developing country and most comparisons were done with developed countries where youth wage subsidy policies have been applied. Literature from developing countries was mainly written in languages that were difficult to understand, such as Spanish. Nevertheless, the challenges were overcome by doing a comparison of this study with other studies done in South Africa.

\section{Conclusion}

This powerful statement by Nolutshungu (2011) is very fitting to close this study: he states that:

tackling the unemployment problem may seem a daunting and insurmountable task. It is going to require statesmanship and fortitude of character as opposed to the opportunism and myopia being practiced by many of our contemporary politicians. But the task is not prohibitively difficult. Before the unemployment problem gets worse, some audacious policy measures need to be implemented, for, at the end of the day, it is only the stroke of the statutory pen that is required. (p. 157)

\section{Acknowledgements}

To God and all who made it happen through their support, thank you.

\section{Competing interests}

The authors declare that they have no financial or personal relationships that may have inappropriately influenced them in writing this article. 


\section{Authors' contributions}

V.N.M. (University of KwaZulu-Natal) was the primary researcher and wrote the manuscript. L.N.G. (University of KwaZulu-Natal) was the primary researcher's supervisor.

\section{References}

Barker, F. (2007). The South African labour market: Theory and practice. (5th edn.). Pretoria: Van Schaik Publishers.

Baskin, J. (1996.) Against the current: Labour and economic policy in South Africa. Johannesburg: Ravan Press.

Coakes, S.J., \& Steed, L.G. (2007). SPSS: Analysis without anguish. Singapore: Kyodo Printing Co.

Leedy, P.D., \& Ormrod, J.E. (2010). Practical research: Planning and design and reporting research. (9th edn.). Upper Saddle River, NJ: Pearson Education.

National Treasury. (2011, February). Discussion paper for public comment: Confronting youth unemployment: Policy options for South Africa. South Africa: Government Printers.
Natrass, N., Wakeford, J., \& Muradzikwa, S. (2002). Macroeconomics: Theory and policy in South Africa. (3rd rev. edn.). Cape Town: David Phillip Publishers.

Nolutshungu, T. (2011). Jobs, jobs, jobs. Sandton: Freemarket Foundation.

Parsons, R. (2009). Zumanomics: Which way to shared prosperity in SA, Challenges for new government. Pretoria: Jacana Media.

Rankin, N., \& Schöer, V. (2011). Youth employment, recruitment and a youth-targeted wage subsidy: Findings from a South African firm level survey. University of the Witwatersrand, Mimeo.

Roux, A. (2008). Everyone's guide to the South African economy. (9th edn.). Cape Town: Zebra Press.

SBP. (2013, February). Headline report: SBP'S SME growth index - Easier, harder for small business in South Africa. Retrieved June 20, 2013, from http://www.sbp.org. za/uploads/media/SME_Growth_Index_-_2012_Headline_Report.pdf

South African Government. (2010). New growth path: The framework. South Africa: Government Printers.

South African Reserve Bank. (2013). Unemployment definition. Retrieved June 10, 2013, from http://www2.resbank.co.za/internet/Glossary.nsf

Statistics South Africa. (2013). Quarterly labour force survey, 1st quarter 2013. Retrieved May 06, 2013, from http://www.statssa.gov.za

Tustin, D.H., Ligthelm, A.A., Martins, J.H., \& Van Wyk., H.J. (2005). Marketing research in practice. Pretoria: Unisa Press.

World Bank. (2009). Employment policy primer, No. 14. Washington, DC: World Bank. 